\title{
Ethical and legal aspects of medical gene editing: towards a new eugenics
}

Ekain PAYÁN ELLACURIA**

Predoctoral researcher, Chair in Law and the Human Genome R.G., Department of Public Law, University of the Basque Country UPV/EHU (Leioa, Spain, 48940)

Summary: 1. Introduction: approach to the classic concept of eugenics. 2. Scope, evolution and brief historical overview. 3. Legal framework in European Union. 4. From eugenics to new eugenics: knowledge and technology, medicalization and non-coercion. 4. The growing role of biotechnological tools in eugenics: CRISPR-Cas9 as a new form of eugenics. 4.2. Advantages and disadvantages of gene editing: weighting of risks and benefits. 5. Final considerations. 6. Bibliography

\begin{abstract}
: eugenics has historically been linked, by its coercive and discriminatory use, to practices of unholy remembrance for humanity. In this sense, it is enough to recall the painful bloodshed committed by the German National Socialist regime. However, advances in biotechnology, and more specifically in the field of genetic engineering, represented by techniques such as CRISPR-Cas9, have reopened an intense ethical and legal debate. This procedure can contribute to the cure and treatment of diseases even before they appear, unlike other existing techniques, in an effective, seemingly harmless and easy way, although it can sometimes entail the assumption of certain risks, as well as the modification of the germ line and, in short, of the human genome itself. In the opinion of some authors, this may mean a return to eugenics. However, in this article, I will try to differentiate exactly what differentiates the new eugenics from the classical trend, explaining the risks and benefits involved and presenting integrative conclusions for the legal fit of new health technologies.
\end{abstract}

\section{Keywords: \\ CRISPR-Cas9 / Eugenics / Gene editing / New biotechnologies / Gene therapy}

\section{Introduction: approach to the classic concept of eugenics}

The main objective of this paper is to introduce the reader to the importance of gene editing in curing serious diseases, and to reject the argument of a return to eugenics. Initially, we will analyse the definitions and the historical context of eugenics, making a comparison between classical and new ones. After that, we will approach the new biotechnologies, in the context of to current legislation, to make an alternative proposal.

\footnotetext{
** Correspondence address: ekain.payan@ehu.eus

The author would like to take this opportunity to thank the support of the Call for Recruitment for the Training of Research Personnel at the UPV/EHU (2016), promoted by the Vice-rectorate for Research of the UPV/EHU in carrying out this work.
} 
At first, I have to say that there is no single, absolute, precise and universal definition of restate which term, not even in the person of its creator, Sir Francis GALTON, in the England of the late nineteenth century.

Eugenics has its etymological origin in the art of good birth ${ }^{1}$, a term introduced by GALTON in his book "Inquiries into Human Faculty and Its Development" (London, 1883) after having been inspired by Charles DARWIN's "On the Origin of Species" in 1859.

However, the definition officially advocated by the author and the "Eugenics Review" was "it is the study of the agencies under social control that improve or impair the racial qualities of future generations either physically and mentally"2. GALTON also defined it as "The science which deals with all influences that improve the inborn qualities of a race; also with those that develop them to the utmost advantage" 3 . Another of the definitions of eugenics is identified with "the application of the biological laws of inheritance to the perfection of the human species"4.

More recently, Daniel Soutullo has advocated the following definition to define eugenics: "a Set of methods aimed at improving the genetic endowment of human populations or individuals, reducing the transmission of genes considered harmful (negative eugenics) or promoting the propagation of genes considered beneficial (positive eugenics)" ${ }^{5}$. Indeed, eugenics has historically manifested itself in two distinct ways: negative ("that which seeks to prevent the reproduction of individuals who are considered to have inferior or undesirable characteristics" ${ }^{6}$ ); and positive ("is aimed at achieving that individuals with characteristics considered to be superior or desirable"7).

However, as I said before, it is an undetermined and subjective concept, since this is a definition that will vary according to the subject -including his or her own circumstances, the historical moment and the society to which he or she belongs- who is questioned about this meaning, showing different parameters what can be considered by each individual as a good life or quality of life.

\footnotetext{
${ }^{1}$ CAMPS, V., “¿Qué hay de malo en la eugenesia?”, Isegoría: Revista de filosofía moral y política, No. 27, 2002, p. 55.

${ }^{2}$ RodRíguez LóPez, B., “¿Qué hay de positivo en la eugenesia positiva?, Anuario de la Facultad de Derecho de la Universidad Autónoma de Madrid - Afduam, No.18, 2014, p. 154.

${ }^{3}$ Galton, F., “Eugenics: its definition, scope and aims”, The American Journal of Sociology, No. 1, Vol. 10, July 1904, pp. 1-25.

${ }^{4}$ CAMPS, V., op. cit., p. 56.

5 Soutullo, D., "Índice de Voces", VV.AA., Romeo Casabona, C.M. (Dir.), Enciclopedia de Bioderecho y Bioética, Inter-University Chair BBVA Foundation - Bizkaia Provincial Council for Law and the Human Genome, University of Deusto and University of the Basque Country UPV/EHU, Ed. Comares, S.L., Bilbao-Granada, Spain, 2011.

${ }^{6}$ Rodríguez LóPEZ, B., “¿Qué hay de positivo en la eugenesia positiva?, op. cit., p. 150; V.V.A.A., Romeo Casabona, C.M. (Ed.), Más allá de la salud. Intervenciones de mejora en humanos, Ed. Comares, S.L., Bilbao-Granada, Spain, 2012, pp. 1-2.

7 Ídem.
} 


\section{Scope, evolution and brief historical overview}

Eugenics has been present in humanity, in one way or another, since the start, to the point that it could be considered as a kind of intrinsic aspiration to the human being in its constant and permanent search for the evolution and improvement of its own species, translated into those people who bring together the best qualities in terms of capacity, strength, intelligence, morality, psychology and health.

Thus, in ancient Greece, in the works of PlAto -"The Republic" and "The Laws"- and in those of ARISTOTLE -"Politics"- already considered the convenience of, for the maintenance and the most efficient management of the ideal city or the polis, its citizens procreating selectively, in such a way that it will be carried out among the most outstanding, eliminating, or at least mitigating, the reproduction of those who do not meet a series of desirable minimum conditions: "As a legislator, you shall make a selection among women, as you have done among men, and you will pair them with each other taking into account all possible similarities"8; "It is necessary, according to our principles, that the relationships of the most outstanding individuals of both sexes be very frequent, and those of the inferior individuals very rare; in addition, it is necessary to raise the children of the former and not of the latter, if we want the flock not to degenerate (...) As for the children of the lower subjects, as well as for those born with some deformity, they will be hidden because it is convenient, somewhere that will be forbidden to reveal. It is the means of preserving in all its purity the race of our warriors" 9 . The same happened in the Renaissance with the work "City of the Sun" by Tommaso CAmpanella: "In fact, the utopian project of Campanella is an eugenic project. There is a community of women, but not any man can have sex with the woman of his choice, but it will depend on the decision of a third party who takes into account certain factors"10 and "The New Atlantis "by Francis BACON.

However, it was in the second half of the nineteenth and at the beginning of the twentieth century when, as a consequence of the fear of biological decadence predicted by intellectuals and politicians of the time, together with the firm conviction about gene determinism ${ }^{11}$ and the growing processes of industrialization, immigration and urbanization that were being established in many countries, its application boomed in Europe (England, France, Austria, Switzerland, Denmark, Finland, Norway and Sweden) and in America (United States of America, Cuba, Brazil, Mexico, Peru and Argentina), being, most probably, the climax of eugenics the one that took place in Germany's National Socialist regime.

\footnotetext{
${ }^{8}$ Cfr. BlÁzquez Ruiz, F.J., Derechos humanos y Proyecto Genoma, Ministry of Health - InterUniversity Chair in Law and the Human Genome, University of Deusto and University of the Basque Country UPV/EHU, Ed. Comares, S.L., Bilbao-Granada, Spain, 1999, p. 175.

${ }^{9}$ Platón, La República, V, 459d,e-460c.

${ }^{10}$ CAnAdy Salgado, J., "Foucault y Campanella: El Cuidado de Sí en La Ciudad del Sol”, Thémata. Revista de Filosofía, No. 47, 2013, p. 67.

${ }^{11}$ At the end of the 19th century, many psychiatrists were losing hope of finding a cure for different mental disorders, because they were convinced that such ailments were strictly hereditary. VILLELA CORTÉS, F. / LinARES SAlGADO, J. E., "Eugenesia. Un análisis histórico y una posible propuesta”, Acta Bioethica, No. 17, Vol. 2, 2011, p. 191.
} 
This constituted the way for the search of perfection that for them enmeshed the purity of the Aryan race and that would ensure the continuity and preservation of the Third Reich, being all this the prelude to one of the most execrable barbarism in the history of humanity: the Holocaust. Thus, first in the Aktion T4 and later in the concentration camps and in the gas chambers, the extermination of thousands of lives was unleashed, which, for the regime, were considered "unworthy of being lived": insane, mentally handicapped, deformed children, Jews, gypsies... ${ }^{12}$. Thus, among the measures implemented the following stand out: forced sterilization of mentally ill persons; the prohibition not only the marriage between Jews and Germans, but also their sexual contact in order to "purify" the German race -which, in reality, manifested a marked anti-Semitism-; euthanasia of the inept ${ }^{13}$; The Lebensborn or Schönenbrunnen ${ }^{14}$ programs for procreation among selected members of the Schutzstaffel (SS) and racially appropriate women, giving economic or social incentives; and campaigns of supervision.

After the end of the Second World War in 1945, and in view of the terror that had hit Europe, several authors, such as Daniel J. KEVLES, came to affirm that eugenics fell into disrepute and that there was a profound slowdown in its development. Before that, the Brazilian zootechnical Octavio DoMINGUES, already in 1929, reasoned: “There is a very foolish and very vulgarized prejudice, which confers an absolute superiority on pure breeds (pseudo-pure, it would be better to say) over the populous nuclei, formed by present-day crossbreeding. I don't know where such a scientifically unfounded idea comes from (...) Well, among humans, that purity of the race is not important for the improvement of the species, since all human races are, more or less, stained by defects, malformations, psychologically bad inheritances. Then, we cannot link the idea of superiority to the idea of pure race" ${ }^{15}$. More precise was Luigi Luca CAVALLI-SFORZA, explaining the polymorphism that exists in the genetics of the vast majority of the population: "There are no pure breeds (...) We can easily realize it. If we study any genetic system, we always find a high degree of polymorphism, that is, genetic variety... What is the point of talking about "purity of the breed" when each population, however small it may be, is variable? (...) So, no genetic purity. In human populations, it simply does not exist”"16.

\footnotetext{
${ }^{12}$ BALlesteros Llompart, J., "Más allá de la eugenesia: el posthumanismo como negación del homo patiens”, Cuadernos de Bioética. Eugenesia en la sociedad actual, No. 77, Vol. 23, January-April 2012, p. 17. Available at: http://aebioetica.org/revistas/2012/23/77/15.pdf [Last consultation: 9th April 2018].

${ }^{13}$ Brock, D.W. / Buchanan, A. / Daniels, N. / Wilker, D., Genética y Justicia, Ed. Cambridge University Press, Madrid, Spain, 2002, p. 34. Moreover, Kein TUCHEL and MÜLLER-HILL make express reference to the euthanasia programme of September 1, 1939, which caused thousands of victims, with a notable presence of children, which they have cited in their works, among others, Carlos María ROMEO CASABONA and Erika MENDES DE CARVALHO.

${ }^{14}$ Romeo Casabona, C.M., Genética y Derecho, Ed. Astrea de Alfredo y Ricardo Depalma, S.R.L., Buenos Aires City, Argentina, 2003, p. 140.

${ }^{15}$ Domingues, O., Hereditariedade e Educação, Ed. Melhoramentos, São Paulo, Brazil, 1929, p. 136.

${ }^{16}$ Cavalli-Sforza, F. / CAVAlli-SForzA, L.L., Quiénes somos. Historia de la diversidad humana, Ed. Crítica, Barcelona, Spain, 2009, p. 255.
} 


\section{Legal framework in European Union}

As for the normative framework of the eugenics in the European Union (hereafter, EU), it is precisely the aforementioned tragic German experience that has led to a total consensus for its unanimous rejection by the EU. This is demonstrated by Article 3 (2) of the Charter of Fundamental Rights of the European Union ${ }^{17}$ and Article 13 of the Oviedo Convention ${ }^{18}$, where eugenics is entirely prohibited. Along the same lines, the EU Member States own internal laws have been expressed.

This means that any kind of gene editing, even for diagnostic, preventive or therapeutic purposes, is prohibited if it alters the germ line and affects the future of the offspring. Some authors have complained that allowing gene editing for therapeutic purposes might bring back us into eugenics practices, this argument is a clear example of the slippery slope. Even though the ban on eugenics is socially and politically accepted, it may be excessive to all genetic medical issues ${ }^{19}$. This also can be deduced from the willingness to renew, as evidenced by the Oviedo Convention Working Group's report ${ }^{20}$, and it is foreseeable that, in the future, it will have to be reviewed on a case-bycase basis.

\footnotetext{
${ }^{17}$ Charter of Fundamental Rights of the European Union (2000/C 364/01), done at Nice on the seventh day of December in the year two thousand. Chapter I: Dignity. Article 3: Right to the integrity of the person. 2. "In the fields of medicine and biology, the following must be respected in particular: the prohibition of eugenic practices, in particular those aiming at the selection of persons”. Available at: http://www.europarl.europa.eu/charter/pdf/text_en.pdf [Last consultation: 9th April 2018].

${ }^{18}$ Convention for the Protection of Human Rights and Dignity of the Human Being with regard to the Application of Biology and Medicine: Convention on Human Rights and Biomedicine, Oviedo (Spain), 4.IV.1997. Chapter IV: Human Genome. Article 13, interventions on the human genome: "An intervention seeking to modify the human genome may only be undertaken for preventive, diagnostic or therapeutic purposes and only if its aim is not to introduce any modification in the genome of any descendants”. Available at: https://rm.coe.int/168007cf98 [Last consultation: 9th April 2018].

1914 . Societies have the authority to regulate science, and scientists have a responsibility to obey the law. However: a. Any constraint of scientific inquiry should be derived from reasonable concerns about demonstrable risks of harm to persons, societal institutions, or society as a whole. Policymakers should refrain from constraining scientific inquiry unless there is substantial justification for doing so that reaches beyond disagreements based solely on divergent moral convictions". THE HINXTON GROUP. AN InTERnATIONAL CONSORTIUM ON STEM CELls, ETHics \& LAW, "Statement on Genome Editing Technologies and Human Germline Genetic Modification”, 2015, p. 6. Available at: http://www.hinxtongroup.org/Hinxton2015_Statement.pdf [Last consultation: 9th April 2018].

20 "It nevertheless agreed unanimously to specify that the provision would need to be reviewed within a certain time (e.g. five years after the entry into force of the Convention) having regard to the current progress in knowledge (...) A representative of the European Community Working Group on Human Embryo and Foetus Protection, agreed that while it was reasonable in the present state of scientific knowledge to prevent all intervention on the reproductive cells, it was nevertheless expedient to insert a revision clause so that technical advances could be taken into account”. CounCIL OF EUROPE, "Convention on the Protection of Human Rights and Dignity of the Human Being with regard to the application of Biology and Medicine: Convention on Human Rights and Biomedicine (ETS N $\left.{ }^{\circ} 164\right)$. Preparatory Work on the Convention", Steering Committee on Bioethics (CDBI), CDBI/INF (2000) 1Provisional, 28 ${ }^{\text {th }}$ June 2000, pp. 64-66. Available at: https://rm.coe.int/16804586b6 [Last consultation: 9th April 2018].
} 


\section{From eugenics to new eugenics: knowledge and technology, medicalization and non-coercion}

As can be seen from the preceding paragraphs, social-darwinistic and hedonistic eugenics was characterised by a number of distinctive features. On one hand, class, racial or socio-political criteria predominated, defending the superiority of certain races as opposed to others that were theoretically inferior; in their absence, his supporters promoted interbreeding to improve races. On the other hand, there was a strong desire for perfection or racial selection. Besides, there were coercive impositions by governments; for example, forced sterilizations in India, prenuptial medical diagnoses in Cyprus and abortions in the event of childbearing in China are recent examples. In the end, understood that people were only marked by their genetic condition -known as determinism or hereditary genetic condition-, and all this in a context of genetic and social pessimism.

Faced with this traditional eugenics, the so-called new eugenics has an exclusive purpose related to medicine and the health of the single individual. Furthermore, the governments no longer participate in these decisions, which are left to the patient or his or her legal representative alone, and which can be taken freely, subject to prior informed consent and genetic-clinical advice. In addition to this, scientific advances authorise us to have knowledge about epigenetics, in other words, about the environmental, cultural, educational, social and vital effects that would affect the mutation and evolution of the same gene (e.g. lifestyle, nutrition...), within the biotechnological flowering that has been experienced since, at least, the complete sequencing of the human genome. Among others, we can mention the Assisted Reproduction Techniques (ART), gene therapy or genetic engineering ${ }^{21}$. The difference in characteristics and objectives is, as will be seen, the reason why we are able to recognize the emergence of a new eugenics.

4.1. The growing role of biotechnological tools in eugenics: CRISPR-Cas9 as a new form of eugenics

As a result of biomedical advances, biomolecular tools for the knowledge and manipulation of genes have been gradually emerging, such as pre-conception diagnosis, pre-implantation genetic diagnosis (in vitro, hereafter, PGD), prenatal diagnosis and postnatal diagnosis. However, it is another mechanism that everyone is talking about. The origin of this one revolutionary gene editing technique dates back to 1993, when the Spanish researcher and microbiologist Francisco Juan Martínez MoJicA discovered the repetition (SRSR, which he would definitively call Short and Regularly Interspaced

\footnotetext{
${ }^{21}$ Romeo Casabona, C.M., Del gen al derecho, Externado de Colombia University, Bogotá, Colombia, 1996, p. 260.
} 
Palindromic Repetitions, hereafter CRISPR) of sequences in the DNA of certain bacteria and which turned out to be a system of immune defence ${ }^{22}$.

We had to wait until 2012, when Emmanuelle CHARPENTIER and Jennifer Anne DOUDNA discovered that the adhesion of endonuclease Cas9 to CRISPR opened the door to edit the human genome ${ }^{23}$. The CRISPR-Cas9 mechanism made it possible to insert, modify or replace DNA sequences, operating as a kind of "molecular scissors" because it had the capacity to "cut and paste". This means that using CRISPR-Cas9 we can modify the genome very precisely, without significant costs ${ }^{24}$ and with a relatively simple applicability in comparison with previous methods.

\subsection{Advantages and disadvantages of gene editing: weighting of risks and benefits}

On the one hand, its advocates -posthumanists or transhumanists- base their arguments on the defence of freedom of research in which it is foreseeable that this technology will progressively optimise its results and security. All of this would make it possible to eliminate some of the most terrible illnesses of genetic origin from the very beginning ${ }^{25}$, even before they become apparent and spread through the organism. This improvement of the technique would give effective fulfilment to the principles of autonomy, charity and justice. Although the technique entails the assumption of certain risks, they are in favour of continuing to experiment in order to reduce them to the minimum: a general prohibition would only contribute to the expansion of black markets and practices not permitted by law.

On the other hand, its opponents -bioconservers- have emphasized the health, ethical and technical risks of today's CRISPR-Cas9, due to its recent appearance. They highlight the efficacy of previous techniques, such as PGD, against CRISPR-Cas9. Thus, they believe that patients and their descendants can suffer an irreparable damage, as their germ line is linked and can be perpetuated through their offspring and cause a change in the human genome. Other arguments are the violation of human dignity; the preservation and sanctification of the human genome -the widespread argument of "playing to be God"-; the argument of the "slippery slope", acting like a domino effect;

\footnotetext{
${ }^{22}$ MojicA, F. J. M. / Juez, G. / RodríGuez-VAlerA, F., “Transcription at different salinities of Haloferax mediterranei sequences adjacent to partially modified Pstl sites”, Molecular Microbiology, No. 3, Vol. 9, August 1993, pp. 613-621.

${ }^{23}$ JineK, M. / Chylinski, K. / FonfarA, I. / HAuer, M. / DoudnA, J.A. / ChARPEnTiER, E., “A Programmable Dual-RNA-Guided DNA Endonuclease in Adaptive Bacterial Immunity, Science, Vol. 337, August 2012, pp. 816-821.

24 “(...) while the use of meganucleases requires 4-5 years of work and a cost of $€ 6,000$ to carry out editing research, ZF nucleases involve a cost of $30.000 €$, the TALENs involve a time of 3-4 months and a cost of $10.000 €$, with the CRISPRCas9 only 2-3 weeks of work and a cost of 20-30 € ". LACADENA, J.R., "Genética y Humanismo. Edición genómica: ciencia y ética”, Revista Iberoamericana de Bioética, No. 3, 2017, p. 3.

${ }^{25}$ DOUdnA, J. A. / CHARPENTIER, E., "The new frontier of genome engineering with CRISPR-Cas9”, Science, Vol. 346, November 2014; LAFountAine, J. S. / FATHE, K. / SMYTH, H. D., "Delivery and therapeutic applications of gene editing technologies ZFNs, TALENs, and CRISPR/Cas9”, International Journal of Pharmaceutics, No. 1, Vol. 494, October 2015, p. 180; LEDFORD, H., "CRISPR, the disruptor”, Nature, Vol. 522, June 2015, pp. 20-24.
} 
and the risk of a return to eugenic practices of unlucky memory for humanity ${ }^{26}$. In summing up, they resist the alteration of the germ line, underlining the primacy of the principles of dignity, equity, identity, precaution, proportionality and responsibility.

\section{Final considerations}

It is clear that today's eugenics has nothing in common with the previous version even though the use of this name brings back memories that we want to avoid completely. The aim of the new eugenics is to cure serious diseases as well as to repair all types of genetic defects, using gene therapies such as CRISPR-Cas9. With this type of new biotechnologies it's not only a desired challenge, but also a goal of real scope.

In order to assess the ethical and legal acceptability of the use of these technologies, the legal goods needing protection must be weighed up, and the right to life and health are always the most important ones. That is the reason why, ethically, there should be no doubt when we have to save a life or achieve the minimum quality of health. Legally, right now those techniques are literally not allowed, but the attempts to include the use of CRISPR-Cas9 inside the general prohibitions of eugenics rules can be considered insufficient.

In my opinion, it would be appropriate to readapt the existing legal criteria to date, inserting into the corresponding legal text the new health technologies which imply therapeutic improvements. In order to achieve this, a prior consensus is required among all scientific, social and political agents to decide when and how to use eugenics, avoiding cases of going beyond health -enhancement- or trying not to take risks that are not acceptable because they don't return higher benefits or rewards, given that zero risk doesn't exist in medicine.

Finally, politicians must not ignore the demands of their citizens: according to a recent study ${ }^{27}$, three out of four people (75\%) are in favour of gene editing for therapeutic purposes in adults.

\section{Bibliography}

BAllesteros LlOMPART, J., "Más allá de la eugenesia: el posthumanismo como negación del homo patiens”, Cuadernos de Bioética. Eugenesia en la sociedad actual, No. 77, Vol. 23, January-April 2012. Available at: http://aebioetica.org/revistas/2012/23/77/15.pdf [Last consultation: 9th April 2018].

BlázQuez RuIZ, F.J., Derechos humanos y Proyecto Genoma, Ministry of Health - Inter-University Chair in Law and the Human Genome, University of Deusto and University of the Basque Country UPV/EHU, Ed. Comares, S.L., Bilbao-Granada, Spain, 1999.

\footnotetext{
${ }^{26}$ LANPhier, E. / Urnof, F. / HAECKER, S. E. / Werner, M. / SMOlEnSKI, J., "Don't edit the human germ line”, Nature, Vol. 519, 2015, pp. 410-411. Available at: https://www.nature.com/news/don-t-editthe-human-germ-line-1.17111 [Last consultation: 9th April 2018].

${ }^{27}$ Gaskell, G. / Bard, I. / Allansdottir, A. / Vieira da Cunha, R. / Eduard, P. / Hampel, J. / Hildt, E. / Hofmaier, C. / Kronberger, N. / Laursen, S. / Meijknecht, A. / Nordal, S. / Quintanilha, A. / Revuelta, G. / Saladié, N. / SAndor, J. / Borlido SAntos, J. / Seyringer, S. / Singh, L. / Somsen, H. / ToOnders, W. / Torgersen, H. / Torre, V. / VArJu, M. / ZwArt, H., "Public views on gene editing and its uses”, Nature Biotechnology, No. 35, November 2017, pp. 1021-1023. Available at: https://www.nature.com/articles/nbt.3958 [Last consulting: 9th April 2018].
} 
Brock, D.W. / Buchanan, A. / Daniels, N. / Wilker, D., Genética y Justicia, Ed. Cambridge University Press, Madrid, Spain, 2002.

CAMPS, V., “¿Qué hay de malo en la eugenesia?”, Isegoría: Revista de filosofía moral y política, No. 27, 2002.

CAnAdy Salgado, J., “Foucault y Campanella: El Cuidado de Sí en La Ciudad del Sol”, Thémata. Revista de Filosofía, No. 47, 2013.

CAvalli-Sforza, F. / CAVAlli-SforzA, L.L., Quiénes somos. Historia de la diversidad humana, Ed. Crítica, Barcelona, Spain, 2009.

Council OF Europe, "Convention on the Protection of Human Rights and Dignity of the Human Being with regard to the application of Biology and Medicine: Convention on Human Rights and Biomedicine (ETS N ${ }^{\circ}$ 164). Preparatory Work on the Convention", Steering Committee on Bioethics (CDBI), CDBI/INF (2000) 1Provisional, 28 ${ }^{\text {th }}$ June 2000, pp. 64-66. Available at: https://rm.coe.int/16804586b6 [Last consultation: 9th April 2018].

Domingues, O., Hereditariedade e Educação, Ed. Melhoramentos, São Paulo, Brazil, 1929.

DOUDNA, J. A. / CHARPENTIER, E., "The new frontier of genome engineering with CRISPR-Cas9", Science, Vol. 346, November 2014.

Galton, F., “Eugenics: its definition, scope and aims”, The American Journal of Sociology, No. 1, Vol. 10, July 1904.

GAskell, G. / Bard, I. / Allansdottir, A. / Vieira dA Cunha, R. / EduARd, P. / HAmpel, J. / Hildt, E. / Hofmaier, C. / Kronberger, N. / Laursen, S. / Meijknecht, A. / Nordal, S. / Quintanilha, A. / Revuelta, G. / SAladié, N. / SAndor, J. / Borlido Santos, J. / SEyringer, S. / Singh, L. / Somsen, H. / Toonders, W. / Torgersen, H. / TORre, V. / VArJu, M. / Zwart, H., "Public views on gene editing and its uses", Nature Biotechnology, No. 35, November 2017. Available at: https://www.nature.com/articles/nbt.3958 [Last consulting: 9th April 2018].

JineK, M. / Chylinski, K. / Fonfara, I. / Hauer, M. / DOUdnA, J.A. / Charpentier, E., “A

Programmable Dual-RNA-Guided DNA Endonuclease in Adaptive Bacterial Immunity, Science, Vol.

337, August 2012.

LACADENA, J.-R., “Genética y Humanismo. Edición genómica: ciencia y ética”, Revista Iberoamericana de Bioética, No. 3, 2017.

LAFountaine, J. S. / FATHE, K. / SMYTH, H. D., "Delivery and therapeutic applications of gene editing technologies ZFNs, TALENs, and CRISPR/Cas9”, International Journal of Pharmaceutics, No. 1, Vol. 494, October 2015.

LANPhiER, E. / URnOf, F. / HAECKER, S. E. / Werner, M. / SMOlEnSKI, J., "Don't edit the human germ line”, Nature, Vol. 519, 2015. Available at: https://www.nature.com/news/don-t-edit-the-human-germline-1.17111 [Last consultation: 9th April 2018].

LEDFORD, H., “CRISPR, the disruptor”, Nature, Vol. 522, June 2015.

MoJiCA, F. J. M. / JuEZ, G. / RodRÍGUEZ-VALERA, F., "Transcription at different salinities of Haloferax mediterranei sequences adjacent to partially modified Pstl sites”, Molecular Microbiology, No. 3, Vol. 9, August 1993.

Platón, La República, V.

RODRÍGUEz LÓPEZ, B., “¿Qué hay de positivo en la eugenesia positiva?, Anuario de la Facultad de Derecho de la Universidad Autónoma de Madrid - Afduam, No.18, 2014.

Romeo Casabona, C.M., Del gen al derecho, Externado de Colombia University, Bogotá, Colombia, 1996.

Romeo Casabona, C.M., Genética y Derecho, Ed. Astrea de Alfredo y Ricardo Depalma, S.R.L., Buenos Aires City, Argentina, 2003.

Soutullo, D., “Índice de Voces”, VV.AA., Romeo CASABOnA, C.M. (Dir.), Enciclopedia de Bioderecho y Bioética, Inter-University Chair BBVA Foundation - Bizkaia Provincial Council for Law and the Human Genome, University of Deusto and University of the Basque Country UPV/EHU, Ed. Comares, S.L., Bilbao-Granada, Spain, 2011.

THE HinXton Group. An InTERnATIONAL CONSORTIUM ON STEM CELls, Ethics \& LAW, "Statement on Genome Editing Technologies and Human Germline Genetic Modification”, 2015. Available at: http://www.hinxtongroup.org/Hinxton2015_Statement.pdf [Last consultation: 9th April 2018].

V.V.A.A., Romeo CASABONA, C.M. (Ed.), Más allá de la salud. Intervenciones de mejora en humanos, Ed. Comares, S.L., Bilbao-Granada, Spain, 2012.

Villela Cortés, F. / Linares SAlgado, J. E., "Eugenesia. Un análisis histórico y una posible propuesta”, Acta Bioethica, No. 17, Vol. 2, 2011. 